\title{
Risk factors associated with SARS-CoV-2 pneumonia in the pediatric population
}

\author{
Moisés Moreno-Noguez ${ }^{1}$, Rodolfo Rivas-Ruiz ${ }^{2 *}$, Ivonne A. Roy-García², Daniel O. Pacheco-Rosas ${ }^{3}$, \\ Sarbelio Moreno-Espinosa ${ }^{4}$, and Andrey A. Flores-Pulido ${ }^{5}$ \\ ${ }^{1}$ Unidad de Medicina Familiar 55, Órgano de Operación Administrativa Desconcentrada Estado de México Oriente, Instituto Mexicano del Seguro \\ Social (IMSS), State of Mexico; ${ }^{2}$ Centro de Adiestramiento en Investigación Clínica, División de Desarrollo de la Investigación, Coordinación de \\ Investigación en Salud, IMSS, Mexico City; ${ }^{3}$ Unidad Médica de Alta Especialidad en Pediatría, Centro Médico Nacional Siglo XXI, IMSS, Mexico \\ City; ${ }^{4}$ Dirección de Enseñanza y Desarrollo Académico, Hospital Infantil de México Federico Gómez, Secretaría de Salud, Mexico City; ${ }^{5}$ Hospital \\ de Especialidades Pediátricas, Centro Regional de Alta Especialidad Chiapas, Secretaría de Salud, Tuxtla Gutiérrez, Chiapas. Mexico
}

\begin{abstract}
Background: Currently, there are a few studies on the clinical characteristics of the pediatric population with COVID-19 and pneumonia. This study aimed to analyze data associated with the development of pneumonia in children and adolescents with SARS-CoV-2 infection throughout Mexico. Methods: We conducted a secondary analysis of the database of the Dirección General de Epidemiología of the Mexican Government. We included children under the age of 19 who were confirmed with SARS-CoV-2 infection by reverse transcription-polymerase chain reaction (RT-PCR) test. The dependent variable was the diagnosis of pneumonia. Odds ratios (OR) and $95 \%$ confidence intervals $(95 \% \mathrm{Cl})$ were calculated. Multiple logistic regression models were performed to adjust factors associated with pneumonia. Results: $A$ total of 1443 children with a COVID-19 diagnosis were included. The median age of the participants was 12 years (interquartile range 25, 75: 5, 16). Pneumonia occurred in 141 children (9.8\%). The main risk factors were age <3 years (OR, 3.5; 95\% Cl, 2.45-5.03); diabetes or obesity (OR, 12.6; 95\% Cl, 4.62-34.91); and immunocompromise (OR, 7.03; 95\% Cl, 3.97-13.61). Conclusions: Children < 3 years with COVID-19 and comorbidities, especially diabetes or obesity, and immunocompromised patients have a higher risk of developing pneumonia.
\end{abstract}

Keywords: Pneumonia. COVID-19. Risk-factors. Pediatrics.

\section{Factores de riesgo asociados con neumonía por SARS-CoV-2 en población pediátrica}

\section{Resumen}

Introducción: Hasta ahora existen pocos estudios sobre las características clínicas de la población pediátrica con neumonía por COVID-19. El objetivo de este estudio fue analizar los datos que se asocian con el desarrollo de neumonía en niños y adolescentes con infección por SARS-CoV-2 en México. Métodos: Se llevó a cabo un análisis secundario de la base de datos de la Dirección General de Epidemiología del Gobierno Mexicano. Se incluyeron menores de 19 años con infección por SARS-CoV-2 confirmada mediante la prueba de retrotranscripción acoplada a la reacción en cadena de la polimerasa

Correspondence:

${ }^{*}$ Rodolfo Rivas-Ruiz

E-mail: rivasrodolfo@gmail.com (http://creativecommons.org/licenses/by-nc-nd/4.0/).
Date of reception: 19-08-2020

Date of acceptance: $25-11-2020$

DOI: 10.24875/BMHIM.20000263
Available online: $23-07-2021$

Bol Med Hosp Infant Mex. 2021;78(4):251-258

www.bmhim.com 
(RT-PCR). La variable dependiente fue el diagnóstico de neumonía. Se calcularon las razones de momios (RM) y los intervalos de confianza del 95\% (IC95\%). Se realizaron modelos de regresión logística múltiple para ajustar los factores asociados a neumonía. Resultados: Se incluyeron 1443 niños con diagnóstico de COVID-19. La mediana de edad de los participantes fue de 12 años (rango intercuartilar 25-75: 5-16). La neumonía se presentó en 141 niños (9.8\%). Los principales factores de riesgo fueron edad < 3 años (RM: 3.5; IC95\%: 2.45-5.03), diabetes u obesidad (RM: 12.6; IC95\%: 4.62-34.91) e inmunocompromiso (RM: 7.03; IC95\%: 3.97-13.61). Conclusiones: Los niños con COVID-19 menores de 3 años y con comorbilidad, especialmente diabetes u obesidad, y los inmunocomprometidos presentan mayor riesgo de desarrollar neumonía.

Palabras clave: Neumonía. COVID-19. Factores de riesgo. Pediatría.

\section{Introduction}

From the first cases of SARS-CoV-2 infection in Wuhan, China, in December 2019 until July 2020, more than 13 million infected people and 500,000 deaths due to this agent have been confirmed'.

Unlike adults, clinical manifestations and the proportion of severe cases-estimated at $5-6 \%$, according to some series ${ }^{2}$-are less frequent in the pediatric population.

Although the pandemic caused by SARS-CoV-2 has affected the pediatric population, this population has been understudied. Moreover, children with coronavirus disease 2019 (COVID-19) present a different behavior from adults ${ }^{3}$. Reports from the pediatric population indicate that COVID-19 is rare in young children, including newborns, even if their immune maturation is incomplete $^{4}$. In the first reports from Wuhan, $20 \%$ of 171 infected children confirmed by reverse transcription-polymerase chain reaction (RT-PCR) test were asymptomatic ${ }^{5}$. When symptoms appear, they consist of low-grade fever lasting 1-2 days before the appearance of respiratory symptoms. There also may be gastrointestinal or nonspecific symptoms such as irritability, rejection of food, or pronounced hypoactivity. The progression to pneumonia, acute respiratory distress syndrome, multiple organ failure, and coagulation disorders occur in a lower percentage than adults ${ }^{6}$.

Pneumonia is the leading risk factor for admission to intensive care unit (ICU), mechanical ventilation, and death in children infected with SARS-CoV-2 ${ }^{7}$. While it was thought that children were protected against this virus, recent reports show that the pediatric population is not excluded from COVID-19 and its complications, possibly due to their immune system immaturity ${ }^{8}$.

Several clinical studies have reported the behavior of COVID-19 in children. In addition to pulmonary manifestations, significant variability of symptoms affecting multiple organs and tissues has been described ${ }^{9}$. Preliminary data from the multinational project CAKE (Critical Coronavirus and Kids Epidemiology), mainly aiming to describe pediatric patients critically ill by COVID-19, indicate a significant variability of symptoms and complications associated with the infection process, including myocarditis ${ }^{10}$.

Pneumonia is one of the main reasons for ICU admission, mechanical ventilation, and death (odds ratio (OR), 10.4; $95 \% \mathrm{Cl}, 5.16-21.2)$. In a European cohort, $73 \%$ of children admitted to the ICU presented pneumonia, compared to $20 \%$ who did not require ICU admission, reflecting the importance of evaluating pneumonia risk factors. Among the risk factors described in these populations are age, sex (male), nutritional status, and comorbidities, which are variable among the different populations. Therefore, a study in the Mexican population is required to determine the risk factors affecting this population ${ }^{11}$.

\section{Methods}

We conducted a secondary analysis of the database of the Dirección General de Epidemiología of Mexico's Ministry of Health. This database is an open database updated with the reports of cases suspected and confirmed by a positive test for SARS-CoV-2 by the Instituto Nacional de Diagnóstico y Referencia Epidemiológica ${ }^{12}$.

The database included 215,656 patients diagnosed with COVID-19, updated to May 23, 2020. Patients under the age of 18 with a positive diagnosis of COVID19 were selected for detection of SARS-CoV-2 by RT-PCR test.

The database has the following variables: identification record, origin (viral respiratory disease monitoring units (USMER), not USMER, not specified), sector (public or private sector), entity, medical unit, sex (female/male, not specified), birth entity, residence entity, municipality, type of patient (ambulatory, hospitalized, or unspecified), entry date, date of initiation of symptoms, date of death (if applicable); pneumonia, age, nationality (Mexican, foreign, unspecified), indigenous-language speaker, diabetes, asthma, immunosuppression, systemic arterial hypertension, cardiovascular 


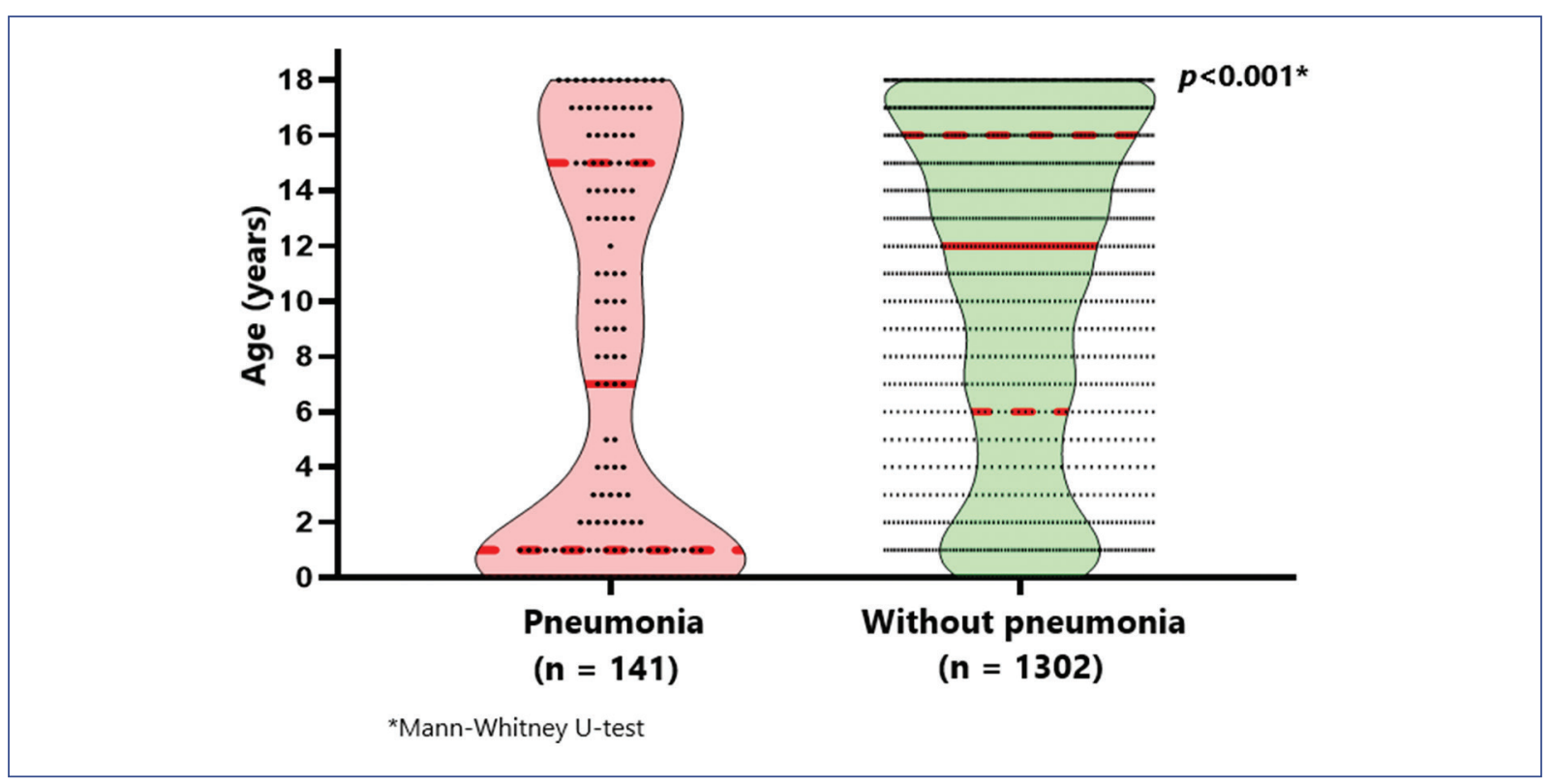

Figure 1. Violin plot. Presence of pneumonia in the pediatric population with a confirmed COVID 19 (coronavirus disease) diagnosis.

comorbidity, obesity, chronic kidney disease (CKD), SARS-CoV-2 test results (positive, negative, pending), and if treated in an ICU. Pneumonia diagnosis was based on clinical signs and radiological findings.

The evaluated risk factors for pneumonia were age, sex, cardiovascular risk, asthma, chronic kidney disease, diabetes, and nutritional status. Admission to the Pediatric ICU (PICU) was evaluated as a secondary outcome. These data were provided by doctors who treat COVID-19 patients in Mexico.

\section{Statistical analysis}

Data selection was performed looking for aberrant data, which were replaced in the case of the age variable with a sex-adjusted linear regression model in ten patients. The model replaced the qualitative variables (diabetes, asthma, obesity, cardiovascular risk, and CKD) that showed a percentage of lost values lower than $0.5 \%$. The pneumonia variable was not imputed.

We performed descriptive statistics. For quantitative variables, normal distribution was corroborated by the Kolmogorov-Smirnov test, assuming a $p$-value $>0.05$ as normal ${ }^{13}$.

These tests determined that age was freely distributed, so it was summarized with the median and interquartile range (IQR 25, 75) represented with a violin plot (Figure 1). The rest of the qualitative variables were summarized as frequencies and percentages.

A bivariate analysis was performed to assess all the possible factors associated with pneumonia using the Pearson's $\chi^{2}$ test to assess clinical significance ${ }^{14}$. The clinical relevance was determined by calculating the OR with $95 \%$ confidence intervals $(95 \% \mathrm{Cl})$.

For the multivariate models, the forward stepwise multivariable logistic regression analysis was used, and the interactions in each of the steps were shown. This analysis was represented with a forest plot (Figure 2) ${ }^{15}$. For the statistical analysis, $R$ software was used on the Jamovi, IBM, SPSS V25, and GraphPad Prism 8 platforms. All statistics used were bilateral (two-tailed).

\section{Results}

A total of 1,443 participants confirmed positive for SARS-CoV-2 by RT-PCR were included. The median age was 12 years, $6.7 \%<1$ year of age, and $15 \%$ between 1 and 3 . Table 1 shows the general characteristics of this population. When assessing the comorbidities of these patients, we found that the most frequent were obesity $(5.7 \%)$, asthma (3.4\%), immunosuppression $(3.2 \%)$, obesity and/or diabetes $(6.5 \%)$, and high cardiovascular risk $(1.5 \%)$. Of the total number of participants, $17.6 \%$ were admitted to the PICU. 
Table 1. Demographic characteristics in the pediatric population with a confirmed diagnosis of COVID-19 (coronavirus disease)

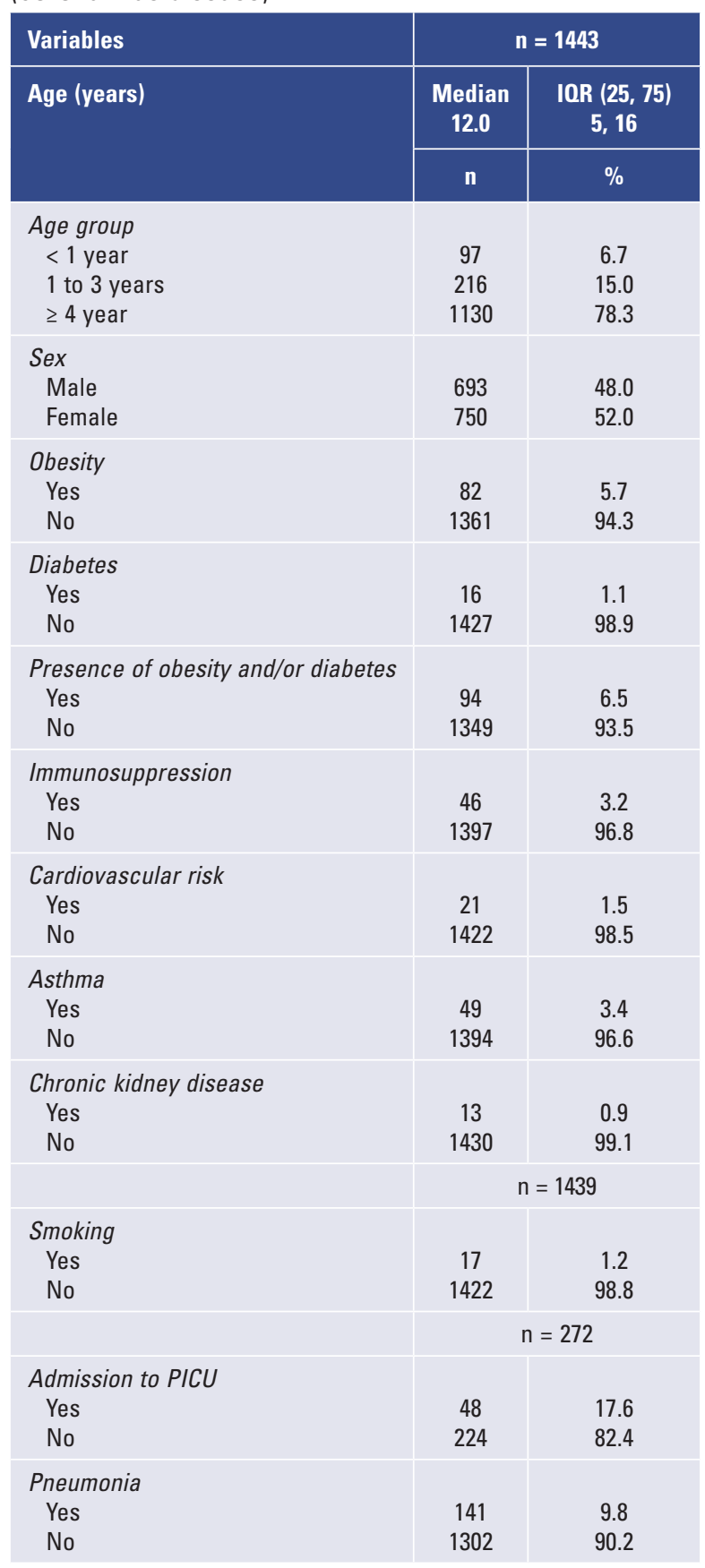

IOR, interquartile range; PICU, Pediatric intensive Care Unit.

Table 2 shows the risk factors associated with pneumonia in the pediatric population with a COVID-19 diagnosis. The percentage of participants with pneumonia was $9.8 \%$. Figure 1 shows that the subjects with pneumonia were significantly younger, with a median age of 7 years (IQR 1, 15), while the children without pneumonia had a median age of 12 years (IQR 6, 16). In the bivariate analysis, the risk factors were age < 1 year (OR, 5.83; $95 \% \mathrm{Cl}, 3.56-9.54)$ and children aged $1-3$ years (OR, 2.64; 95\%IC, 1.72-4.06). Furthermore, diabetes showed an OR of $12.61(95 \% \mathrm{Cl}$, 4.62-34.41); obesity and/or diabetes an $\mathrm{OR}$ of $2.94(95 \% \mathrm{Cl}, 1.75-4.95)$. When evaluated alone, obesity showed not to be a significant risk factor for pneumonia. In addition, the immunosuppression variable showed an OR of $7.35(95 \% \mathrm{Cl}, 3.97-7.35)$. The rest of the evaluated factors did not show statistical significance.

The forward stepwise logistic regression method was used to show the main variables associated with the presence of pneumonia (Table 3). In the third step of the model, the obesity and/or diabetes variable showed an OR of $2.95(95 \% \mathrm{Cl}, 1.68-5.17)$, the immunosuppression variable showed an OR of $7.63(95 \% \mathrm{Cl}, 4.01-$ $14.51)$, age $<1$ year showed an OR of $5.89(95 \% \mathrm{Cl}$, 3.54-9.79), and age between 1-3 years showed an OR of $2.193(95 \% \mathrm{Cl}, 1.21-3.96)$.

\section{Discussion}

To the best of our knowledge, this is the first study to analyze risk factors associated with pneumonia in children with COVID-19. This study includes the most significant number of children with confirmed SARS-CoV-2 and pneumonia, allowing an analysis of risk factors that influenced the development of this complication. This research was possible thanks to the joint work of healthcare professionals and doctors who have registered the cases of COVID-19.

Pneumonia is a well-known risk factor for children with COVID-19 for both death and admission to intensive care ${ }^{7}$. One of the main risk factors for a bad prognosis is lung damage. Whang et al. found that having more than three lung segments involved was associated with a high risk of developing severe COVID-19 in children and was the only risk factor for a bad prognosis with an OR of $25(95 \% \mathrm{Cl}, 2.52-248)^{16,17}$.

However, the risk factors associated with the development of pneumonia have not been studied. This investigation focused on the factors associated with the development of pneumonia in a cohort of children with confirmed SARS-CoV-2 infection.

Our results showed that $9.8 \%$ of infected children develop pneumonia, and the youngest children were the most affected. In particular, those $<3$ years of age have three times more risk than older children, even in the models adjusted for the main variables. 
Table 2. Risk factors associated with the presence of pneumonia in the pediatric population with a COVID-19 diagnosis

\begin{tabular}{|c|c|c|c|c|c|c|c|}
\hline \multirow{2}{*}{$\begin{array}{l}\text { Variables } \\
\begin{array}{l}\text { Age (dichotomic) } \\
<1 \text { year } \\
1 \text { to } 3 \text { years } \\
\geq 4 \text { years }\end{array}\end{array}$} & \multicolumn{2}{|c|}{$\begin{array}{l}\text { With pneumonia } \\
n=141(\%)\end{array}$} & \multicolumn{2}{|c|}{$\begin{array}{l}\text { Without pneumonia } \\
n=1302(\%)\end{array}$} & \multirow{2}{*}{$\begin{array}{l}\text { OR } \\
\\
5.83 \\
2.64 \\
\text { Ref }\end{array}$} & \multirow{2}{*}{$\begin{array}{l}95 \% \text { CI } \\
\\
3.56,9.54 \\
1.72,4.06\end{array}$} & \multirow{2}{*}{$\begin{array}{l}p \text {-value* } \\
\\
<0.001 \\
<0.001\end{array}$} \\
\hline & $\begin{array}{l}29 \\
35 \\
77\end{array}$ & $\begin{array}{c}29.9 \\
16.2 \\
6.8\end{array}$ & $\begin{array}{c}68 \\
181 \\
1053\end{array}$ & $\begin{array}{l}70.1 \\
83.8 \\
93.2\end{array}$ & & & \\
\hline $\begin{array}{l}\text { Sex } \\
\text { Male } \\
\text { Female }\end{array}$ & $\begin{array}{l}58 \\
83\end{array}$ & $\begin{array}{c}8.4 \\
11.1\end{array}$ & $\begin{array}{l}635 \\
667\end{array}$ & $\begin{array}{l}91.6 \\
88.9\end{array}$ & $\begin{array}{l}0.73 \\
\text { Ref }\end{array}$ & $0.51,1.04$ & 0.085 \\
\hline $\begin{array}{l}\text { Obesity } \\
\text { Yes } \\
\text { No }\end{array}$ & $\begin{array}{c}13 \\
128\end{array}$ & $\begin{array}{c}15.9 \\
9.4\end{array}$ & $\begin{array}{c}69 \\
1233\end{array}$ & $\begin{array}{l}84.1 \\
90.6\end{array}$ & $\begin{array}{l}1.81 \\
\text { Ref }\end{array}$ & $0.97,3.37$ & 0.056 \\
\hline $\begin{array}{l}\text { Diabetes } \\
\text { Yes } \\
\text { No }\end{array}$ & $\begin{array}{c}9 \\
132\end{array}$ & $\begin{array}{c}56.2 \\
9.3\end{array}$ & $\begin{array}{c}7 \\
1295\end{array}$ & $\begin{array}{l}43.8 \\
90.7\end{array}$ & $\begin{array}{l}12.61 \\
\text { Ref }\end{array}$ & $4.62,34.41$ & $<0.001$ \\
\hline $\begin{array}{l}\text { Presence of obesity } \\
\text { Yes } \\
\text { No }\end{array}$ & $\begin{array}{c}21 \\
120\end{array}$ & $\begin{array}{c}22.3 \\
8.9\end{array}$ & $\begin{array}{c}73 \\
1229\end{array}$ & $\begin{array}{l}77.7 \\
91.1\end{array}$ & $\begin{array}{l}2.94 \\
\text { Ref }\end{array}$ & $1.75,4.95$ & $<0.001$ \\
\hline $\begin{array}{l}\text { Immunosuppression } \\
\text { Yes } \\
\text { No }\end{array}$ & $\begin{array}{c}19 \\
122\end{array}$ & $\begin{array}{c}41.3 \\
8.7\end{array}$ & $\begin{array}{c}27 \\
1275\end{array}$ & $\begin{array}{l}58.7 \\
91.3\end{array}$ & $\begin{array}{l}7.35 \\
\text { Ref }\end{array}$ & $3.97,13.61$ & $<0.001$ \\
\hline $\begin{array}{l}\text { Cardiovascular risk } \\
\text { Yes } \\
\text { No }\end{array}$ & $\begin{array}{c}3 \\
138\end{array}$ & $\begin{array}{c}14.3 \\
9.7\end{array}$ & $\begin{array}{c}18 \\
1284\end{array}$ & $\begin{array}{l}85.7 \\
90.3\end{array}$ & $\begin{array}{l}1.55 \\
\text { Ref }\end{array}$ & $0.45,5.33$ & 0.483 \\
\hline $\begin{array}{l}\text { Asthma } \\
\text { Yes } \\
\text { No }\end{array}$ & $\begin{array}{c}5 \\
136\end{array}$ & $\begin{array}{c}10.2 \\
9.8\end{array}$ & $\begin{array}{c}44 \\
1258\end{array}$ & $\begin{array}{l}89.8 \\
90.2\end{array}$ & $\begin{array}{l}1.05 \\
\text { Ref }\end{array}$ & $0.41,2.69$ & 0.917 \\
\hline $\begin{array}{l}\text { Chronic kidney dise } \\
\text { Yes } \\
\text { No }\end{array}$ & $\begin{array}{c}3 \\
138\end{array}$ & $\begin{array}{l}23.1 \\
9.7\end{array}$ & $\begin{array}{c}10 \\
1292\end{array}$ & $\begin{array}{l}76.9 \\
90.3\end{array}$ & $\begin{array}{l}2.80 \\
\text { Ref }\end{array}$ & $0.76,10.32$ & 0.105 \\
\hline $\begin{array}{l}\text { Smoking } \\
\text { Yes } \\
\text { No }\end{array}$ & $\begin{array}{c}\mathrm{n}=139 \\
2 \\
137\end{array}$ & $\begin{array}{c}11.8 \\
9.6\end{array}$ & $\begin{array}{c}n=1300 \\
15 \\
1285\end{array}$ & $\begin{array}{l}88.2 \\
90.4\end{array}$ & $\begin{array}{l}1.25 \\
\text { Ref }\end{array}$ & $0.28,5.52$ & 0.768 \\
\hline $\begin{array}{l}\text { Admission to PICU } \\
\text { Yes } \\
\text { No }\end{array}$ & $\begin{array}{c}n=119 \\
26 \\
93\end{array}$ & $\begin{array}{l}54.2 \\
41.5\end{array}$ & $\begin{array}{c}n=153 \\
22 \\
131\end{array}$ & $\begin{array}{l}45.8 \\
58.5\end{array}$ & $\begin{array}{l}1.66 \\
\text { Ref }\end{array}$ & $0.88,3.11$ & 0.109 \\
\hline
\end{tabular}

OR, odds ratio; Cl, confidence interval; PICU, Pediatric Intensive Care Unit; * Pearson's X2.

Obesity is one of the most controversial risk factors. In a study of mortality of children with COVID-19 in Mexico, obesity was found not to be an associated risk factor ${ }^{7}$. In contrast, in a group of children hospitalized at a children's hospital in New York, $50 \%$ of which were Hispanic, obesity was the main comorbidity (22\%) and was significantly associated with mechanical ventilation in children $>2$ years of age ( 6 of 9 [67\%] vs. 5 of 25 $[20 \%]]^{18}$. Twenty percent of the children who were hospitalized for COVID-19 in ICUs in Canada showed obesity ${ }^{19}$. However, we found that the obesity/type-2 diabetes pair was associated with the development of pneumonia with an OR of $2.9(95 \% \mathrm{Cl}, 1.75-4.95)$. The idea of combining obesity with diabetes implies that children with obesity and diabetes share the same intrinsic factors since both are well-known inflammatory disease ${ }^{20}$. Adult patients with COVID-19 and obesity have a worse prognosis than patients with normal weight ${ }^{21}$. In a Mexican cohort of 177,133 adults with suspected SARS-CoV-2 infection, 51,633 infected subjects and 5,332 deaths were identified. The only comorbidity that conferred an increased risk of death exclusively for COVID-19 was obesity (HR 1,261; $95 \% \mathrm{Cl}, 1,109-1,433)^{22}$. 


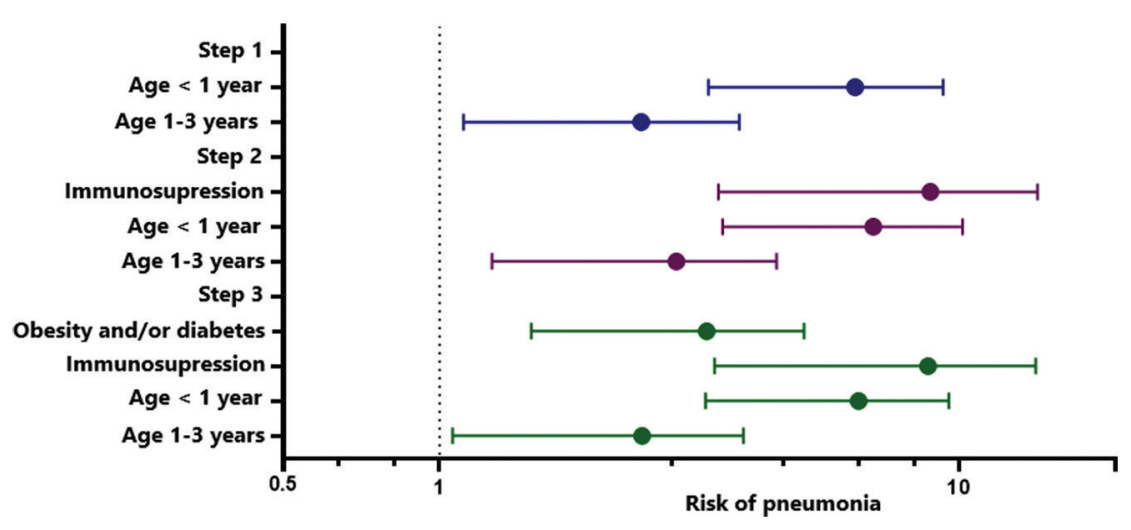

Figure 2. Forest plot. Risk factors associated with pneumonia in the pediatric population with a confirmed COVID 19 (coronavirus disease) diagnosis. Multivariate models.

Table 3. Risks associated with pneumonia in the pediatric population with COVID 19 (coronavirus disease). Multivariate analysis.

\begin{tabular}{|c|c|c|c|c|c|c|}
\hline & Variable & B & SE & $p$-value* & OR & CI $95 \%$ \\
\hline \multirow[t]{3}{*}{ Step 1} & Age $(<1$ year $)$ & 1.763 & 0.251 & $<0.001$ & 5.832 & $3.56,9.54$ \\
\hline & Age ( 1 to 3 years) & 0.791 & 0.289 & 0.006 & 2.205 & $1.25,3.88$ \\
\hline & Age ( $\geq 4$ years) & \multicolumn{5}{|c|}{ Reference } \\
\hline \multicolumn{7}{|l|}{$\mathrm{R}^{2}=0.074$} \\
\hline \multirow[t]{4}{*}{ Step 2} & Immunosuppression & 2.004 & 0.326 & $<0.001$ & 7.724 & $4.07,14.63$ \\
\hline & Age $(<1$ year $)$ & 1.841 & 0.256 & $<0.001$ & 6.302 & $3.81,10.40$ \\
\hline & Age ( 1 to 3 years) & 0.941 & 0.297 & 0.002 & 2.561 & $1.43,4.58$ \\
\hline & Age ( $\geq 4$ years) & \multicolumn{5}{|c|}{ Reference } \\
\hline \multicolumn{7}{|l|}{$\mathrm{R}^{2}=0.120$} \\
\hline \multirow[t]{5}{*}{ Step 3} & Obesity and/or diabetes & 1.082 & 0.286 & $<0.001$ & 2.951 & $1.68,5.17$ \\
\hline & Immunosuppression & 2.031 & 0.328 & $<0.001$ & 7.631 & $4.01,14.51$ \\
\hline & Age (< 1 year) & 1.774 & 0.259 & $<0.001$ & 5.892 & $3.54,9.79$ \\
\hline & Age ( 1 to 3 years) & 0.785 & 0.303 & 0.009 & 2.193 & $1.21,3.96$ \\
\hline & Age ( $\geq 4$ years) & \multicolumn{5}{|c|}{ Reference } \\
\hline$R^{2}=0.138$ & & & & & & \\
\hline
\end{tabular}

$\mathrm{B}$, beta exponent; $\mathrm{SE}$, standard error; $\mathrm{OR}$, odds ratio; $95 \% \mathrm{Cl}$, confidence interval at $95 \%$.

In a systematic review that examined the main effects of obesity in children with SARS-CoV-2 infection, the following factors that compromise the functioning of organs and systems in obese individuals were associated: excessive adipose tissue, lean mass deficit, insulin resistance, dyslipidemia, hypertension, high levels of proinflammatory cytokines, and low intake of essential nutrients. These factors are also associated with damage of the immune, cardiovascular, respiratory, and urinary systems and modification of the intestinal microbiota (dysbiosis) $^{23}$. 
In this study, we demonstrated for the first time that children with obesity/diabetes have a 3-fold higher risk $(p<0.001)$ of pneumonia, even in models adjusted for other well-known factors such as immunosuppression.

The multivariate model proposed in this study found that children with obesity $<3$ years of age are at high risk of pneumonia.

Our country has one of the highest child obesity rates. Consequently, the mortality rate in Mexico is higher than other countries with more cases, such as China or European countries, but similar to that of the United States $^{24}$.

From an epidemiological analysis, this finding has potential biases. One of them is that only the children registered with a positive RT-PCR test were considered for the analysis. Therefore, this sample can be an over-selected sample, where the risk factors are exacerbated. Also, it has not been possible to analyze the effect of other factors such as duration of chronic comorbidity, the status of immunizations, breastfeeding history, or other nutritional variables. However, since patients come from all over the Mexican Republic, we consider it represents what is happening in our country.

Conducting studies with a public database, such as the Epidemiology Department of the Ministry of Health, is an advantage that makes it possible to evaluate the effects of the pandemic in real-time. These types of studies help to improve decision-making by clinicians or decision-makers. In this article, where pneumonia is the leading risk factor for death in children, we showed that isolation measures should be stricter in children < 3 years of age, with obesity, diabetes, and those immunocompromised. These children should continue to be isolated within the "new normal" strategy. This analysis will allow first-contact physicians, pediatricians, and infectious disease physicians to identify children with a high risk of developing pneumonia. It could be relevant as a basis for intensifying control strategies for significant comorbidities, including obesity or diabetes, and immunocompromised patients, although obesity was already established in the pediatric population previously to the pandemic. It is essential to consider that social isolation measures and staying at home can reduce children's physical activity and increase bad habits, such as a sedentary lifestyle and sugar overeating due to prolonged television or playing video games. Therefore, it is important to endorse a balanced diet and plan a series of physical activities indoors to avoid promoting the vicious $\mathrm{cycle}^{25}$.
In conclusion, we found that age (children $<3$ years) and obesity/type 2 diabetes pair are the main risk factors for developing pneumonia when children have been infected with SARS-CoV-2.

\section{Ethical disclosures}

Protection of human and animal subjects. The authors declare that no experiments were performed on humans or animals for this study.

Confidentiality of data. The authors declare that they have followed the protocols of their work center on the publication of patient data.

Right to privacy and informed consent. The authors have obtained the written informed consent of the patients or subjects mentioned in the article. The corresponding author has this document.

\section{Conflicts of interest}

The authors declare no conflict of interest.

\section{Funding}

None.

\section{Acknowledgments}

This work is part of initiative $\mathrm{M}$, which promotes local scientific publications. We are grateful to the health workers who are fighting this pandemic.

\section{References}

1. Johns Hopkins University and Medicine. COVID-19 Dashboard by the Center for Systems Science and Engineering (CSSE) at Johns Hopkins University (JHU). Coronavirus Resource Center. Baltimore: Johns Hopkins University \& Medicine; 2020. Available at: https://coronavirus.jhu.edu/map. html

2. Eastin C, Eastin T. Epidemiological characteristics of 2143 pediatric patients with 2019 coronavirus disease in China. J Emerg Med. 2020;58:7123.

3. Tagarro A, Epalza C, Santos M, Sanz-Santaeufemia FJ, Otheo E, Moraleda C, et al. Screening and severity of coronavirus disease 2019 (COVID-19) in children in Madrid, Spain. JAMA Pediatr. 2020;e201346.

4. Kollmann T, Kampmann B, Mazmanian S, Marchant A, Levy O. Protecting the newborn and young infant from infectious diseases: lessons from immune ontogeny. Immunity. 2017; 46:350-63.

5. Lu S, Lin J, Zhang Z, Xiao L, Jiang Z, Chen J, et al. Alert for non-respiratory symptoms of coronavirus disease 2019 (COVID-19) patients in epidemic period: a case report of familial cluster with three asymptomatic COVID-19 patients. J Med Virol. 2021;93:518-21.

6. Chen N, Zhou M, Dong X, Qu J, Gong F, Han Y, et al. Epidemiological and clinical characteristics of 99 cases of 2019 novel coronavirus pneumonia in Wuhan, China: a descriptive study. Lancet. 2020;395:507-13.

7. Rivas-Ruiz R, Roy-García IA, Ureña-Wong KR, Aguilar-Ituarte F, Vázquez-de Anda GF, Gutiérrez-Castañón $P$, et al. Factores asociados a muerte en niños con COVID-19 en México. Gac Med Mex. 2020;156:526-32.

8. Ciaglia E, Vecchione C, Puca AA. COVID-19 infection and circulating ACE2 levels: protective role in women and children. Front Pediatr. 2020;8:206. 
9. She J, Liu L, Liu W. COVID-19 epidemic: disease characteristics in children. J Med Virol. 2020;92:747-54.

10. González-Dambrauskas S, Vásquez-Hoyos P, Camporesi A, Díaz-Rubio F Piñeres-Olave BE, Fernández-Sarmiento, et al. Pediatric critical care and COVID19. Pediatrics. 2020;146:e20201766.

11. Götzinger F, Santiago-García B, Noguera-Julián A, Lanaspa M, Lancella L, Calò Carducci FC, et al. COVID-19 in children and adolescents in Europe: a multinational, multicentre cohort study. Lancet Child Adolesc Health 2020;4:653-61.

12. Secretaría de Salud de México. Datos Abiertos - Dirección General de Epidemiología. México: Secretaría de Salud; 2020. Available from: https:// www.gob.mx/salud/documentos/datos-abiertos

13. Rivas-Ruiz R, Moreno-Palacios J, Talavera JO. Diferencia de medianas con la $U$ de Mann-Whitney. Rev Med Inst Mex Seguro Soc. 2013; 51:414-9.

14. Flores-Ruiz E, Miranda-Novales MG, Villasís-Keever MA. El protocolo de investigación VI: cómo elegir la prueba estadística adecuada. Estadística inferencial. Rev Alerg Mex. 2017;64:364-70.

15. Berea-Baltierra R, Rivar-Ruiz R, Pérez-Rodríguez M, Palacios-Cruz L, Moreno J, Talavera JO. Del juicio clínico a la regresión logística. Rev Med Inst Mex Seguro Soc. 2014;52:192-7.

16. Wang Y, Zhu F, Wang C, Wu J, Liu J, Chen X, et al. Children hospitalized with severe COVID-19 in Wuhan. Pediatr Infect Dis J. 2020;39:e91-4.

17. Li Y, Shi J, Xia J, Duan J, Chen L, Yu X, et al. Asymptomatic and symptomatic patients with non-severe coronavirus disease (COVID-19) have similar clinical features and virological courses: a retrospective single-center study. Front Microbiol. 2020;11:1570.
18. Zachariah $\mathrm{P}$, Johnson CL, Halabi KC, Ahn D, Sen Al, Fischer A, et al Epidemiology, clinical features, and disease severity in patients with coronavirus disease 2019 (COVID-19) in a Children's Hospital in New York City, New York. JAMA Pediatr. 2020;174:e202430.

19. Shekerdemian LS, Mahmood NR, Wolfe KK, Riggs BJ, Ross CE, McKiernan $C A$, et al. Characteristics and outcomes of children with coronavirus disease 2019 (COVID-19) infection admitted to US and Canadian Pediatric Intensive Care Units. JAMA Pediatr. 2020;174:868-73.

20. Cox AJ, West NP, Cripps AW. Obesity, inflammation, and the gut microbiota. Lancet Diabetes Endocrinol. 2015;3:207-15.

21. Cai SH, Liao W, Chen SW, Liu LL, Liu SY, Zheng ZD. Association between obesity and clinical prognosis in patients infected with SARS-CoV-2. Infect Dis Poverty. 2020;9:80.

22. Bello-Chavolla OY, Bahena-López JP, Antonio-Villa NE, Vargas-Vázquez A, González-Díaz A, Márquez-Salinas A, et al. Predicting mortality due to SARS-CoV-2: a mechanistic score relating obesity and diabetes to COVID-19 outcomes in Mexico. J Clin Endocrinol Metab. 2020;105:dgaa346.

23. Nogueira-de-Almeida CA, Del Ciampo LA, Ferraz IS, Del Ciampo IRL, Contini AA, Ued F da V. COVID-19 and obesity in childhood and adolescence: a clinical review. J Pediatr (Rio J). 2020;96:546-58.

24. Castagnioli R, Votto M, Licari A, Brambilla I, Bruno R, Perlini S, et al. Severe acute respiratory syndrome coronavirus 2 (SARS-Cov-2) infection in children and adolescents: a systematic review. JAMA Pediatr. 2020;174:882-9.

25. Calcaterra V, Vandoni M, Pellino VC, Cena H. Special attention to diet and physical activity in children and adolescents with obesity during the coronavirus disease-2019 pandemic. Front Pediatr. 2020;8:407. 